\title{
Mesleki Yeterlik Algıları Ölçeğinin Geliştirilmesi ve Uygulaması
}

\section{Development and Application of Professional Competency Perceptions \\ Scale}

Feyzi KAYSI' ${ }^{1}$

\begin{abstract}
Alıntılama: Kaysi, F. (2020). Mesleki yeterlik algıları ölçeğinin geliştirilmesi ve uygulaması. Ulusal Eğitim Akademisi Dergisi (UEAD), 4(1), 29-48.
\end{abstract}

Geliş tarihi:

25 Şubat 2020

Kabul tarihi:

22 Nisan 2020

(C) UEAD 2020

Tüm hakları saklıdır.

Özet: Meslek yüksekokullarının temel amacı ilgili oldukları sektördeki firmaların beklentilerini karşılayacak yeterlikteki ara elemanları yetiştirmektir. Bu kapsamda verilen mesleki eğitim ile öğrencilerin veya mezunların yeterlikleri önem arz etmektedir. Bu çalışmanın amacı meslek yüksekokulu öğrencilerinin mesleklerine yönelik yeterlik algılarını belirlemektir. Çalışma nicel araştırma yöntemlerinden tarama modelinde bir araştırma olarak tasarlanmıştır. Çalışma kapsamında Mesleki Yeterlik Algısı Ölçeği geliştirilmiştir. 218 katılımcıdan alınan verilerle ölçeğin geliştirilmesine yönelik çalışmalar yapılmıştır. Bu kapsamda açımlayıcı ve doğrulayıcı faktör analizleri yapılarak ölçek maddelerinin geçerlik ve güvenirlik testleri tamamlanmıştır. Geliştirilen ölçek 37 maddeden oluşmaktadır. Ölçeğin tamamına yönelik Cronbach's Alpha değeri ,852 ve KMO değeri ,955 olarak belirlenmiştir. Ölçeğin uygulanması sürecinde 438 katılımcı çalışmada yer almıştır. Çalışmanın bulguları arasında, katılımcıların mesleki yeterlik algılarında cinsiyet değişkenine göre kadınlar lehine anlamlı farklılık tespit edilmiştir. Yaş değişkenine göre mesleki ilgi boyutunda 21 yaş ve üstü katılımcılar lehine anlamlı farklılık tespit edilmiştir. Son olarak öğrenim görülen program değiş̧kenine göre de Elektrik programı lehine anlamlı farklılık tespit edilmiştir. Çalışmanın sonuçları arasında, ölçeğin geçerli ve güvenilir olduğu ve öğrencilerin mesleki yeterlik algılarını ölçek için uygun bir ölçme aracı olduğu yer almaktadır. Ayrıca, katılımcıların üniversite tercihlerinde, öğrenim gördükleri mesleki programa yönelik mesleki yeterlilik ve ilgilerinin etkili olduğu ifade edilebilir. Çalışmanın önerileri arasında, farklı birimlerde öğrenim gören öğrenciler için araştırmaların yapılabileceği yer almaktadir.

Anahtar kelimeler: mesleki eğitim, meslek yüksekokulları, mesleki yeterlik algısı, kişisel yeterlik, mesleki ilgi.

Received:

25 February 2020
Abstract: One of the purpose of vocational schools is to train staff members who have expectations of firms in the sector. In this context, the competence of students or graduates in vocational education is important. The aim of this study is to investigation of perceptions of vocational school students' competence towards their

${ }^{1}$ Dr. Ögrr. Ü., İstanbul Üniversitesi-Cerrahpaşa, fkaysi@istanbul.edu.tr, ORCID ID:0000-0001-6681-4574 
Accepted:

22 April 2020

(C) UEAD 2020

All rights reserved. profession. The study was conducted using a screening model which is one of the quantitative research methods. Within the scope of the study, Professional Competence Perception Scale was developed. Studies on the development of the scale were carried out with data from 218 participants. In this context, confirmatory factor analysis and then exploratory factor analysis were performed and the validity and reliability tests of the scale items were completed. The developed scale consists of 37 items. Cronbach's Alpha value ,852 and KMO value for the entire scale were determined as ,955. 438 participants stated in implementation of the scale. Among the findings of the study, there was a significant difference in participants' perception of professional competence in favor of women according to gender. According to the age variable, a significant difference was found in favor of participants aged 21 and over in terms of professional interest.. Finally, significant differences were found in favor of the Electricity program according to the program variable under study. The results of the study include that the scale is valid and reliable and that students' perceptions of professional competence are an appropriate measurement tool for the scale. In addition, it can be stated that the professional competence and interests of the participants towards the vocational program they are learning are effective in their university choices. Among the suggestions of the study, research can be made for students studying in different units.

Keywords: vocational education, vocational school, perception of professional competence, personal competence, professional interest.

\section{Giriş}

Bireyler çeşitli nedenlerle yüksek öğretim düzeyindeki programları tercih edebilmektedir. $\mathrm{Bu}$ nedenler arasında seçtikleri alana duydukları ilgi, merkezi yerleştirme puanları, alanın kişilik özellikleri ile uyum hissi, mezuniyet sonrası iş bulma imkanı, cinsiyet, yaş, ailenin etkisi, maddi kazanının yeterli görülmesi, mezun olduğu lise türü ve şans gibi faktörlerin etkili olduğu görülmüştür (Dinç, 2008; Korkut-Owen, Kepir, Özdemir, Ulaş ve Yılmaz, 2012; Kuijpers ve Meijers 2012; Pappas ve Kounenou, 2011). Bu tercih nedenleri ile birlikte, zamanla öğrenim gördükleri programlardaki deneyimleri neticesinde bireylerin mesleki yeterlilik algıları da şekillenmeye başlamaktadır. Bu algının oluşmasındaki önemli etkenlerden birisi de mesleki ilgidir. Özellikle meslek seçiminde bireylerin mesleğe yönelik ilgisi ön plana çıkabilmektedir. Bireylerin kariyer planlamasındaki ilk adımın ilgi alanlarının belirlenmesi olması ve bu alana yönelik güçlü ve zayıf yönlerinin farkında olması gerekir (Özdaşl1, 2008). Bu nedenle, bireylerin kendilerini tanıması ve mesleki yeterliklerinin farkında olmaları beklenmektedir.

Bireylerin kendilerini tanıma ve yeterliklerinin farkında olmasını sağlamanın çeşitli yöntemleri olabilir. Bunlar arasında, bireylerin öz-yeterliklerini ölçebilecek ölçme araçlarını kullanmaları ifade edilebilir. Bu noktada yeterlik kavramının iyi ifade edilmiş ve öğrenilmiş olmasına ihtiyaç vardır. Öz-değerlendirme kavramı, bireylerin bir performansı başarı ile 
gerçekleştirme sürecinde kendilerine ilişkin yargısı şeklinde tanımlanmıştır (Bandura, 1997). Genel ve özel yeterlilikleri kapsayan öz-değerlendirme prosedürlerinin kullanılması, mesleki eğitimde yer alan öğrencilerin öğrenmelerini, işyeri ortamlarına entegre etmelerine yardımcı olmanın bir yoludur (Panadero, Garcia ve Fraile, 2018). Diğer bir ifadeyle, öğrencilerin özdeğerlendirme yapmaları, istihdam edilmelerine de kolaylık sağlayabilecektir. Üniversite öğrencilerinin öz-yeterliklerini belirleme süreçlerinde öğretim elemanlarının da görevleri bulunmaktadır. Öğretim elemanlarının öğrencilere performanslarını nasıl değerlendirebilecekleri hakkında bilgi vermeleri gerekir (Panadero, Garcia ve Fraile, 2018). Bu sayede öğrencilerin daha doğru ölçümleri yapmaları ve daha doğru sonuçların ortaya çıkarılması sağlanabilir.

Mesleki eğitimde yeterlilik kavramının önemli olduğunu belirtilmektedir (Nokelainen ve diğ., 2018; Tyson, 2018). Yeterlilik, bir bireyin belirli durumlarla başa çıkma veya bir görevi veya işi başarılı bir şekilde tamamlama kapasitesi şeklinde ifade edilebilir (Ellström ve Kock, 2008). Mesleki eğitimde yeterlilik kavramıyla birlikte mesleki kimlik kavramı da öne çıkmaktadır. Mesleki kimlik, öğrencilerin öğrenmeleri ve performanslarının ayrılmaz bir parçası olan mesleki eğitimin önemli bir sonucudur (Klotz ve diğ., 2014). Mesleki kimliğin kazandırılması ile, öğrencilerin mesleki algılarının beklenen düzeyde olması hedeflenerek, mesleki programın amacının gerçekleşmesi sağlanabilir. Buradan hareketle, öğrencilerin mesleki yeterliliklerinin beklenilen düzeyde olduğu ifade edilebilir. Mesleki yeterlilik, mesleki bir uygulamada beklenen faaliyet için ortaya çıkan potansiyel şeklinde tanımlanmaktadır (Lindberg ve Rantatalo, 2015). Yeterlilik kavramı, mesleki değerlendirmenin hedef yapısı olarak bilgi kavramından daha değerlidir (Deutscher ve Winther, 2018). Bu nedenle yetkinlik kavramıla ilgili farklı tanımlar alanyazında yer almıştır. Yetkinlik kavramı bireyin mesleki birikimlerine entegre edilmiş bilgi, beceri ve tutumları kullanarak gerçekleştirme yeteneği olarak tanımlanmıştır (Mulder, Weigel ve Collins, 2006). Aynı zamanda mesleki eğitim standartları arasında asgari performans gereksinimleri yer almaktadır (Tūtlys ve Aarna, 2017). Bu asgari performans gereksinimlerinin yerine getirilmesi, mesleki eğitim standartlarından bazılarının karşılandığı şeklinde yorumlanabilir. Asgari performans ve yetkinlik arasında, yetkinliğin asgari performansın çok ötesine geçtĭgi ifade edilmiş̧ir (Mulder ve Winterton, 2017).

Meslek yüksekokullarının (MYO) amaçları arasında mesleki eğitimin niteliğini ve yeterliliğini yükseltmek yer almaktadır (İçli, 2007). MYO’lar öğrencilere kazandırdıkları temel becerilerle birlikte mesleki anlamda da yeterlilik ve nitelikler kazandırmaktır (Turan, 2002). Bu 
bakımdan yeterlilik kavramı mesleki eğitimin en önemli bileşenlerinden birisi olarak ifade edilmektedir (Barrick, 2019). Mesleki eğitimde bireylerin, dünyanın dört bir yanındaki insanlarla hareket etme ve etkileşim kurma yeteneği ön planda tutulmalıdır (Pylväs ve Nokelainen, 2018). MYO'larda gerçekleşen mesleki eğitim ile bireylerin mezuniyet sonrası ilgi duydukları iş alanlarında istihdam edilebilir durumda olmaları hedeflenmektedir. Öğrenenlere sunulan öğretimin niteliği, süreç içerisinde almış oldukları mesleki ve alan bilgisine yönelik yeterlilikleri hakkındaki olumlu tutumlarına bağlıdır (Harper ve Daane, 1998). Bu sebeple öğrenenlerin mesleki yeterliklerinin ve dolayısıyla mesleklerine yönelik olumlu tutumlarının arttırılması, mesleki eğitimin niteliğini arttırmaktadır. Sezgin (2009, 58), mesleki eğitimi, bireylerin mezun olduktan sonra ilgili meslek alanında çalışabilmesi için gerekli olan mesleki yeterliklerin kazandırılması şeklinde ifade etmiştir. Leney (2002) ise, mesleki ve teknik eğitimi bireylerin çalışma ortamında kullanabilecekleri gerekli beceri ve yeterliklerle donatılması şeklinde tanımlamıştır. Bu bağlamda yeterlilik, yapılacak iş için kişiden yerine getirmesi veya göstermesi beklenen performans olarak ifade edilebilir. Mesleki eğitim sistemindeki yeterlilik, nispeten düşük vasıflı istihdam için işlevsel istihdam edilebilirliği belirtir (Brockmann, Clarke, Méhaut ve Winch, 2008). Sektör firmalarında beklenen düzeyde performansın sergilenebilmesinin göstergelerinden en önemlisi çalışanların sahip oldukları yeterliliklerdir. Bu nedenle firmalar işe eleman alımlarında önemli gördükleri bazı yeterlikleri göz önünde bulundurmaktadır. Bunlar arasında en önemli iki yeterlik, teknik beceri ve tecrübeye sahip olmaktır (Kayır ve diğ., 2006). Mesleki programlardaki öğrenciler dört dönem boyunca edindikleri deneyim ile birlikte aldıkları akademik başarı sonucu mezun olmaktadırlar. Buna mukabil istihdam edilecekleri sektör firmaları tarafından beklenen yeterliklerinin düşük düzeyde olduğu ifade edilmektedir (Vurgun, 2008). Sektörün beklediği yeterliklerin kısmen karşılanması nedeniyle mezunların iş piyasasında çalışabilmeleri için ek sertifikasyonlar talep edilebilmektedir (Gül-Koçak, 2006). Bu durum hem mezunlar hem de firmalar için zaman kaybına neden olabilmektedir. Ayrıca alınacak sertifikalardaki finansal boyut da ya firma tarafından ya da mezunlar tarafından karşılanmaktadır.

Mesleki eğitim, bireylere öğrenim gördükleri alanlara yönelik mesleki beceriler kazandırmayı amaçlamaktadır. Bu amaç çerçevesinde, bireylere mesleki becerilerini geliştirici imkanlar ve uygulamalar sunulmaktadır. Bu uygulamalar sonucunda, beklenen düzeyde mesleki yeterlik gelişimi gösterdiği değerlendirilen kişiler, mesleki programlardan mezun olabilmektedir. Bununla birlikte mezunların veya öğrenenlerin de bu mesleki yeterliklere yönelik algıları da 
önemlidir. Çünkü bu algı, yani bireyin mesleğini gerçekleştirmeye yönelik hazır olup olmadığı algısı, doğrudan mesleğindeki uygulamalarını etkileyecektir. Diğer bir ifadeyle, bireyin mezuniyet sonrası öğrenim gördüğü mesleki programla ilgili bir firmada istihdam olması, mesleki yeterlik algısının düzeyine bağlıdır. Bu çalışmanın amacı, meslek yüksekokulu öğrencilerinin mesleki yeterlik algılarının farklı değişkenler çerçevesinde incelenmesini sağlamaktır. $\mathrm{Bu}$ amaç doğrultusunda önce Mesleki Yeterlik Algısı ölçeği geliştirilmiş ve bu ölçek çerçevesinde aşağıdaki sorulara cevaplar aranmıştır.

1. Öğrencilerin mesleki yeterlik algıları ne düzeydedir?

2. Öğrencilerin mesleki yeterlik algıları cinsiyet değişkenine göre farklılaşmakta mıdır?

3. Öğrencilerin mesleki yeterlik algıları lise mezuniyet türlerine göre farklılaşmakta mıdır?

4. Öğrencilerin mesleki yeterlik algıları öğrenim türlerine göre farklılaşmakta mıdır?

5. Öğrencilerin mesleki yeterlik algıları yaş değişkenine göre farklılaşmakta mıdır?

6. Öğrencilerin mesleki yeterlik algıları çalışma durumlarına göre farklılaşmakta mıdır?

7. Öğrencilerin mesleki yeterlik algıları öğrenim gördükleri programa göre farklılaşmakta midir?

\section{Yöntem}

\section{Araştırmanın Modeli}

Çalışma nicel bir araştırma olarak tasarlanmıştır. Bu bakımdan çalışmanın deseni betimsel tarama şeklinde ifade edilebilir. Tarama modelini belirlenmiş grubun bazı özelliklerini tarif edebilmek için verilerin toplanmasının amaçlanması şeklinde ifade edilmektedir (Büyüköztürk, Çakmak, Akgün, Karadeniz ve Demirel, 2008). Tarama modelleri ile geçmişte veya günümüzde var olan durumların olduğu gibi betimlendiği, çalışmaya konu olan şey, birey ya da nesnenin, kendi koşulları içinde ve olduğu gibi tanımlandığı şeklinde ifade edilmektedir (Karasar, 2009).

\section{Ölçek Madde Havuzunun Oluşturulması}

Üniversite öğrencilerinin Mesleki Yeterlik algılarını ölçmek amacıyla hazırlanması planlanan ölçek için öncelikle alan yazındaki literatür üzerinden araştırmalar yapılmıştır. Buna ek olarak öğrenciler ve öğretim elemanlarıyla yapılan resmi olmayan görüşmeler sonucunda madde yazımları tamamlanmıştır. Bu aşamalar sonucunda 41 maddelik bir havuz oluşturulmuştur. Madde havuzundaki ifadelerin kontrol edilmesi ve maddelerin yapı geçerliliği için üç alan uzmanı belirlenmiştir. Üç alan uzmanından alınan geribildirimlerle 3, 7, 12 ve 18 numaralı maddeler 
Kaysi (2020)

çıkarılmıştır. Böylece ölçek geliştirme çalışmasına 37 madde ile devam edilmiştir. Ortaya çıkan madde havuzu göz önüne alınarak, ölçeğin geliştirilmesi aşaması için ihtiyaç duyulan katılımcı sayısının yakalanması amaçlanmıştır. Faktör analizi esnasında 40’tan fazla madde içermeyen ölçeklerde 200 bireylik örneklem büyüklüğünün yeterli olduğu belirtilmiştir (Comrey, 1988). Bu bağlamda, ölçeğin geliştirilmesi sürecinde 200'den fazla katılımcıya ulaşılması hedeflenmiştir.

\section{Ölçeğin Geliştirilmesi Aşamasındaki Katılımcılar}

Ölçek geliştirme çalışması 2017-2018 akademik yılında gerçekleştirilmiştir. Bu kapsamda İstanbul'daki bir devlet üniversitesinin meslek yüksekokulunda öğrenim gören toplam 218 katılımcı ile çalışılmıştır. Katılımcılara çalışma hakkında detaylı bilgilendirmeler yapılmış ve katılımcıların tamamı çalışmaya gönüllü olarak dahil olmuştur. Bu katılımcılardan; 40’1 Elektronik Haberleşme Teknolojisi, 45'i Elektrik, 42'si Elektronik Teknolojisi, 52'si Kontrol ve Otomasyon Teknolojisi ve 39'u Radyo ve Televizyon Teknolojisi Programı öğrencisidir. Beşli likert türünde hazırlanan ölçekte '1-1.80 arası' kesinlikle katılmıyorum, '1.81-2.60 arası' katılmıyorum, '2.61-3.40 arası' ne katılıyorum ne de katılmıyorum, '3.41-4.20 arası' katılıyorum ve '4.21-5.00 arası' kesinlikle katılıyorum şeklinde puanlanmıştır.

\section{Açımlayıcı Faktör Analizi}

Katılımcılardan elde edilen veriler dijital ortamlara aktarılmıştır. Sonraki aşamada ise katılımcı görüşleri SPSS 21 paket programı ile açımlayıcı faktör analizine tabi tutulmuştur. Yapılan analizlere yönelik sonuçlar Tablo 1'de verilmiştir. 
Tablo 1: Açımlayıcı Faktör Analizi Sonuçları

\begin{tabular}{|c|c|c|c|}
\hline \multirow[t]{2}{*}{ Madde } & \multicolumn{2}{|c|}{$\begin{array}{l}\text { Faktörler } \\
\text { Yükleri }\end{array}$} & \multirow{2}{*}{$\begin{array}{l}\text { Madde } \\
\text { F3 } \\
\end{array}$} \\
\hline & F1 & F2 & \\
\hline 9: Benden beklenen görevleri yerine getiririm. & ,823 & & \\
\hline 19: Çalışma arkadaşlarımla iyi ilişkiler kurarım. & 823 & & \\
\hline 26: Üstlenmem gereken etik sorumluluğun bilincindeyim. & ,823 & & \\
\hline 20: Dürüst ve insanlara karşı saygılı olmayı bir ilke olarak kabul ederim. &, 800 & & \\
\hline $\begin{array}{l}\text { 25: Kanunlara uyarak, iş yaptığım firmanın geçerli yönetmeliklerini ve politikalarını } \\
\text { uygularım. }\end{array}$ & ,783 & & \\
\hline 24: Çalışırken, görevime uygun giysiler giyerim. & ,783 & & \\
\hline 23: Çalışma saatlerine uyarım. & ,781 & & \\
\hline 8: Mesleğimin gerekliliklerini yerine getiririm. & 779 & & \\
\hline 22: Mola verdikten sonra çalışmaya zamanında başlarım. & ,771 & & \\
\hline 1: Ekip üyeleriyle uyum içinde çalışırım. & ,756 & & \\
\hline 6: Beraber çalıştığım kişilerin karşılaştığı sorunlarda, kendilerine yardımcı olurum. & 756 & & \\
\hline 27: Alınması gereken iş sağlığı ve güvenliği tedbirlerini bilirim. & ,744 & & \\
\hline 5: Sorunları ekip çalışmasıyla çözeriz. &, 732 & & \\
\hline 10: Çalışanların performanslarını objektif olarak değerlendiririm. & ,730 & & \\
\hline 4: Ekip üyeleri tarafindan sevildiğimi düşünürüm. & ,709 & & \\
\hline 11: Çalışanların performanslarını objektif olarak denetlerim. & 704 & & \\
\hline 28: İş sağlı̆̆ ve güvenliği tedbirlerini uygularım. & 697 & & \\
\hline 13: İlgi duyduğum konularda araştırma yaparım. & 682 & & \\
\hline 21: Teknolojik cihazları iş ortamında kullanırım. & 603 & & \\
\hline 29: Karşılaştığım sorunları çözerim. &, 594 & & \\
\hline 30: Mesleğimle ilgili güncel makinaları/cihazları kullanırım. & & ,830 & \\
\hline 41: Mesleğimle ilgili işlerde karşılaştığım sorunları çözerim. & &, 821 & \\
\hline 2: Mesleğimle ilgili güncel yazılımları kullanırım. & & ,819 & \\
\hline 39: Başladığım işleri başarıyla tamamlarım. & & ,809 & \\
\hline 40: Mesleğime karşı ilgimin yeterli olduğunu düşünüyorum. & & ,778 & \\
\hline 31: Mesleki olarak yeterli düzeyde uygulama becerisine sahibim. & & ,758 & \\
\hline 37: Çalışma hayatında, mesleğimle ilgili karşılamam gereken yeterlikleri bilirim. & & ,746 & \\
\hline 38: Çalışma hayatında, mesleğimle ilgili karşılamam gereken yeterliklere sahibim. & & ,745 & \\
\hline 33: Hata, sorun ve yeni durumları öngörerek planlama yaparım. & & ,741 & \\
\hline 35: Türkçeyi doğru ve etkili kullanırım. & & 727 & \\
\hline 36: Mesleki olarak zamanla kendimi geliştirmem gerektiğini bilirim. & & 689 & \\
\hline 32: İhtiyaç halinde temel matematiksel işlemleri yaparım. & & 637 & \\
\hline 34: En az bir yabancı dil kullanarak mesleğime yönelik bilgileri anlarım. & &, 532 & \\
\hline 14: Fuar, Teknik Gezi, Seminer vb. mesleğimle ilgili etkinlere katılırım. & & & ,795 \\
\hline 16: Teknolojideki gelişmeleri alanıma uygulamak için araştırmalar yaparım. & & & ,745 \\
\hline 15: Yenilikleri sürekli takip ederim. & & & ,736 \\
\hline 17: Öğrendiklerimi yeni durumlara uygularım. & & &, 609 \\
\hline Faktör Özdeğerleri & 20,541 & 3,384 & 1,847 \\
\hline Açıklanan Varyans & 55,515 & 9,145 & 4,992 \\
\hline Toplam Açıklanan Varyansın & 55,515 & 64,660 & 69,652 \\
\hline KMO Yeterlilik Ölçütü & & ,955 & \\
\hline Bartlett's Testi & & $\begin{array}{r}7800,094 \\
\mathrm{p}=, 00\end{array}$ & $s d=666$ \\
\hline $\begin{array}{r}\text { Faktörlerin Cronbach's Alpha Katsayısı } \\
\text { Tüm Değişkenlerin Cronbach's Alpha Katsayıs1 }\end{array}$ & ,975 & $\begin{array}{r}, 974 \\
, 852 \\
\end{array}$ & ,955 \\
\hline
\end{tabular}

Tablo 1'e göre, 1, 4, 5, 6, 8, 9, 10, 11, 13, 19, 20, 21, 22, 23, 24, 25, 26, 27, 28 ve 29. maddeler "Görev Sorumluluğu Algısı (GSA)", 2, 30, 31, 32, 33, 34, 35, 36, 37, 38, 39, 40 ve 41. maddeler "Mesleki Yetkinlik Algısı (MYA)" ve 14, 15, 16 ve 17. maddeler "Mesleki İlgi Algısı (MİA)" boyutlarında yer almıştır. Ölçeğe ait KMO yeterlilik değeri ,955 olarak bulunmuş ve bu değere göre 
örneklem büyüklüğünün faktör analizi için "mükemmel" olduğu sonucuna ulaşılmıştır (Çokluk, Şekercioğlu ve Büyüköztürk, 2012). Ölçek geliştirme aşamasında ölçek boyutları ve ölçeğin tamamına yönelik Cronbach's alpha değeri ,852 ile ,975 arasında bulunmuştur. Cronbach's alpha değerinin .80 'nin üzerinde olması ölçeğin güvenirliğinin yüksek olduğunu göstermektedir (Field, 2005). Ölçeğe yönelik toplam açıklanan varyans 69,652 olarak belirlenmiştir. Birden fazla faktörlü ölçeklerde, açılanan varyansın \% 40 ve \% 60 arasında olması yeterlidir (Çokluk ve diğ., 2012).

\section{Doğrulayıcı Faktör Analizi}

Açımlayıcı faktör analizi sonucunda 37 maddenin tamamının ölçekte olduğu gibi kalması sonucuna ulaşılmıştır. Bununla birlikte Lisrel programı ile gerçekleştirilen doğrulayıcı faktör analizi ile maddeler ve ölçeğin boyutları arasındaki ilişkiler Şekil 1'de verilmiştir.

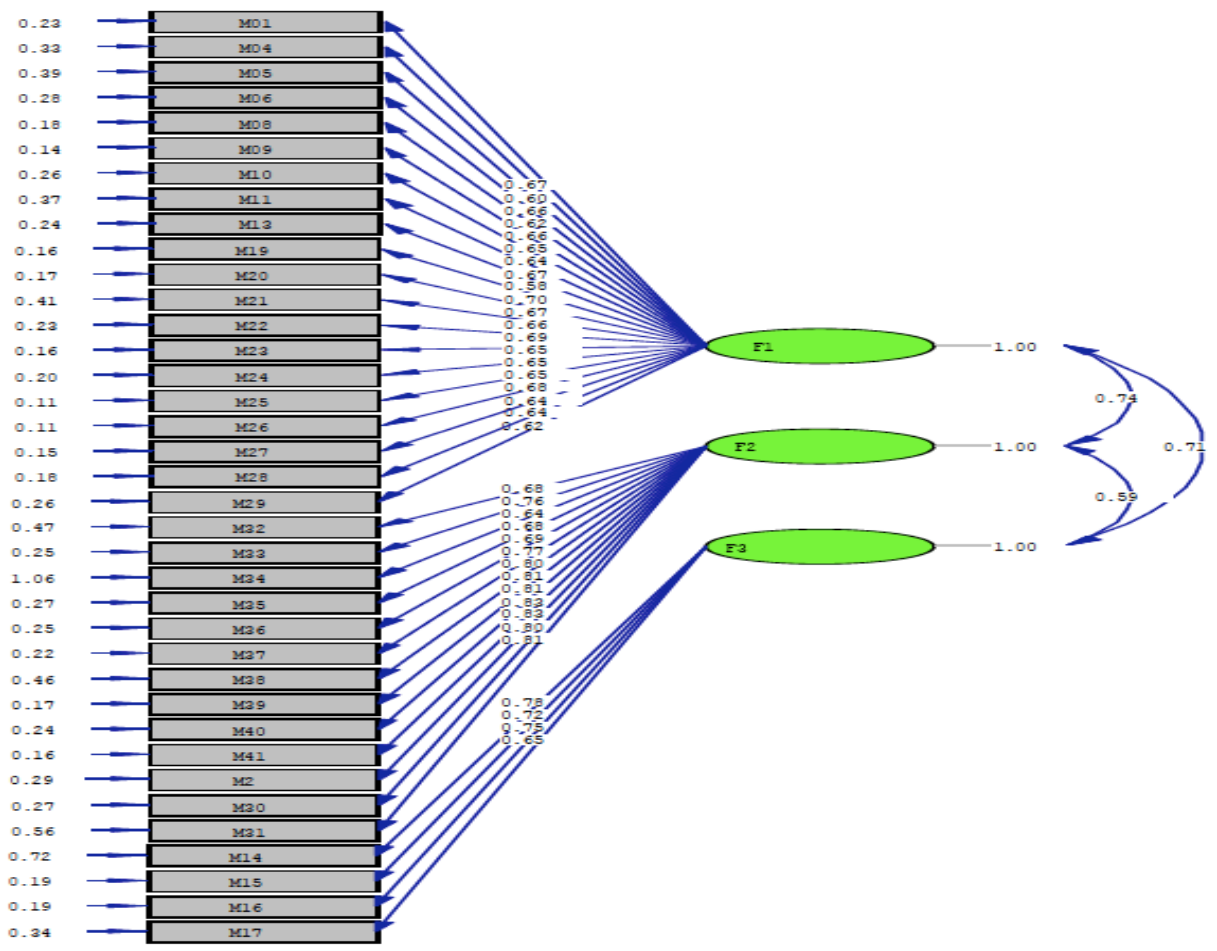

\section{Şekil 1: Doğrulayıcı Faktör Analizi Sonuçları}

Şekil 1'de verilen sonuçlara ek olarak, Chi-Square=1320.80, sd=612, P-değeri=0.000, RMSEA $=0.076$ ve $\chi^{2} / \mathrm{sd}=2,15$ olarak belirlenmiştir. $\chi^{2 / \mathrm{sd}}$ değerinin üçten küçük olmas mükemmel düzeyde uyumun varlığı olarak ifade etmektedir (Schreiber vd., 2006). Ayrıca RMSEA değerinin 0,08'den küçük olması uyumun iyi olduğunu göstermektedir (Çokluk ve diğ., 2012). $\mathrm{NFI}=0.97, \mathrm{CFI}=0.98, \mathrm{IFI}=0.98, \mathrm{RFI}=0.96, \mathrm{SRMR}=0.052$ ve $\mathrm{GFI}=0.84$ olarak ölçülmüştür. Yapılan 
bu ölçümler sonucunda; NFI, CFI, IFI ve RFI değerlerinin mükemmel, GFI ve SRMR kabul edilebilir uyum ölçütlerine sahip olduğu anlaşılmıştır (Schermelleh-Engel \& Moosbrugger, 2003; Baumgartner \& Homburg, 1996).

\section{Ölçeğin Uygulanması}

Ölçek geliştirme süreçleri 2017-2018 akademik y1lında, ölçeğin uygulanması ise 20182019 akademik y1lında gerçekleştirilmiştir. Bu bakımdan ölçeğin geliştirilmesi sürecinde yer alan katılımcıların, uygulama sürecinde yer almaması sağlanmıştır. Ölçeğin uygulanması aşamasında, çalışmada yer alan katılımcılara yönelik bazı bilgiler Tablo 2'de verilmiştir.

Tablo 2: Ölçeğin Uygulamasına Katılan Katılımcılara Dair Bazı Bilgiler

\begin{tabular}{llll}
\hline Değişken & Özellik & f & \% \\
\hline \multirow{2}{*}{ Cinsiyet } & Kadın & 73 & 16,7 \\
& Erkek & 365 & 83,3 \\
\hline \multirow{2}{*}{ Lise Mezuniyet Türü } & Genel & 107 & 24,4 \\
& Meslek & 331 & 75,6 \\
\hline \multirow{4}{*}{ Program } & Elektrik & 71 & 16,2 \\
& Elektronik & 117 & 26,7 \\
& Kontrol ve & 162 & 37,0 \\
& Otomasyon & & \\
\multirow{2}{*}{ Sınıf } & Radyo ve Televizyon & 88 & 20,1 \\
\hline \multirow{2}{*}{ Öğrenim Türü } & 1. Sinıf & 159 & 36,3 \\
& 2. Sinıf & 279 & 63,7 \\
\hline \multirow{2}{*}{ Yaş } & Normal Öğretim & 235 & 53,7 \\
& İkinci Öğretim & 203 & 46,3 \\
\hline Bir İşyerinde Çalışıor & 18-20 arası & 280 & 63,9 \\
mu? & 21 ve üstü & 158 & 36,1 \\
\hline & Evet & 187 & 42,7 \\
& Hayır & 251 & 57,3 \\
\hline & Toplam & 438 & 100,0 \\
\hline
\end{tabular}

Tablo 2 incelendiğinde, katılımcılardan 73'ünün $(\% 16,7)$ kadın ve 365'inin $(\% 83,3)$ erkek olduğu görülmektedir. Lise mezuniyet türlerine göre 107 katılımc1 $(\% 24,4)$ genel liseden ve 331 katılımc1 $(\% 75,6)$ meslek lisesinden mezun olmuştur. Bu katılımcılardan 71'i $(\% 16,2)$ Elektrik, 117'si (\%26,7) Elektronik Teknolojisi, 162'si (\%37,0) Kontrol ve Otomasyon Teknolojisi ve 88'i $(\% 20,1)$ Radyo ve Televizyon Teknolojisinde öğrenim görmektedir. 159 katılımcı $(\% 36,3)$ birinci sınıfta, 279 katılımcı $(\% 63,7)$ ise ikinci sınıfta öğrenim görmektedir. Normal öğretimde $235(\% 53,7)$ ve ikinci öğretimde $203(\% 46,3)$ katııımcı çalışmaya katılmıştır. Ayrıca katılımcılardan 280’i 
$(\% 63,9)$ 18-20 yaş aralığındayken, 158'i $(\% 36,1) 21$ yaş ve üstünde olduğunu ifade etmiştir. Son olarak katılımcılardan 187'si $(\% 42,7)$ hali hazırda bir işyerinde çalıştığını ve 251 'i $(\% 57,3)$ çalışmadığını dile getirmiş̧ir.

\section{Verilerin Çözümlenmesi ve Yorumlanması}

Ölçeğin geliştirilmesi aşamasında SPSS 21.0 paket programıyla açımlayıcı faktör analizi ve Lisrel paket program ile de doğrulayıcı faktör analizi süreçleri tamamlanmıştır. Ölçeğin uygulanması aşamasında elde edilen verilerin çeşitli analiz teknikleriyle karşılaştırılmıştır. Yapılan analizler için bağımsız gruplar $\mathrm{t}$ testi ve tek yönlü varyans analizi kullanılmıştır. Tek yönlü varyans analizinde hangi gruplar arasında anlamlı fark olduğu Scheffe testlerine göre belirlenmiştir. Yapılan değerlendirmelerde katılımcıların mesleki yeterlik algı düzeyleri Tablo 3’teki değerlere göre yorumlanmıştır.

Tablo 3: Ortalama Değerleri Yorumlamak için Kullanılan Puan Aralıkları ve Düzeyleri

\begin{tabular}{ll}
\hline Değer Aralıkları & Düzeyler \\
\hline $1.00-1.80$ & Çok düşük (Kesinlikle katılmıyorum) \\
$1.81-2.60$ & Düşük (Katılmıyorum) \\
$2.61-3.40$ & Orta (Ne katılıyorum ne de katılmıyorum) \\
$3.41-4.20$ & Yüksek (Katılıyorum) \\
$4.21-5.00$ & Çok yüksek (Kesinlikle katıllyorum) \\
\hline
\end{tabular}

\section{Bulgular}

Katılımcıların mesleki yeterlik algılarını ölçek amacıyla geliştirilen ölçeğin analiz edilmesi sonucunda elde edilen bulgular bu bölümde sunulmuştur. Ölçeğe ve alt boyutlarına ait skewness (çarpıklık) ve kurtosis (basıklık) değerleri normal dağılımın yorumlanabilmesi amacıyla incelenmiştir. Bu değerlere yönelik bulgular Tablo 4'te verilmiştir.

Tablo 4: Ölçek boyutlarının skewness (çarpıklık) ve kurtosis (basıklık) değerleri

\begin{tabular}{lrrrr}
\hline & \multicolumn{1}{c}{ GSA } & \multicolumn{1}{c}{ MYA } & \multicolumn{1}{c}{ MIA } & \multicolumn{1}{c}{ TÜM } \\
\hline $\mathbf{n}$ & 438 & 438 & 438 & 438 \\
$\boldsymbol{x}$ & 4,35 & 4,00 & 3,89 & 4,16 \\
Skewness & $-1,604$ & $-1,013$ &,- 680 & $-1,406$ \\
Kurtosis & 1,783 & 1,307 &, 176 & 1,614 \\
\hline
\end{tabular}

Tablo 4 incelendiğinde, katılımcıların Mesleki Yeterlik Algılarının GSA boyutunda çok yüksek, MYA ve MİA boyutlarında ve ölçeğin tamamında yüksek olduğu ifade edilebilir. Ayrıca 
ölçeğin tamamı ve alt boyutlarına yönelik basıklık ve çarpıklık değerleri \pm 2.0 arasında olduğu görülmektedir. Bu değer ile dağılımın normallikten sapmadığı ifade edilebilir (Kalaycı, 2009).

Katılımcıların mesleki yeterlik algılarını belirtmek amacıyla verdikleri yanıtlar üzerinden yapılan cinsiyet değişkeni bağımsız gruplar t-testi sonuçları Tablo 5'te verilmiştir.

Tablo 5: Cinsiyet Değişkenine Göre Bă̆ımsız Gruplar t-testi Sonuçları

\begin{tabular}{|c|c|c|c|c|c|c|c|}
\hline & & & & & \multicolumn{3}{|c|}{ T testi } \\
\hline \multicolumn{2}{|c|}{ Cinsiyet } & $\mathbf{n}$ & $\bar{x}$ & SS & $\mathbf{t}$ & sd & $\mathbf{p}$ \\
\hline \multirow{2}{*}{ GSA } & Kadın & 73 & 4,68 &, 417 & 5,407 & 436 &, $000^{*}$ \\
\hline & Erkek & 365 & 4,28 & ,618 & & & \\
\hline \multirow{2}{*}{ MYA } & Kadın & 73 & 4,38 & 663 & 5,177 & 436 &, $000^{*}$ \\
\hline & Erkek & 365 & 3,91 & ,720 & & & \\
\hline \multirow{2}{*}{ MİA } & Kadın & 73 & 4,27 & ,719 & 4,370 & 436 & ,000* \\
\hline & Erkek & 365 & 3,81 & ,849 & & & \\
\hline \multirow{2}{*}{ TÜM } & Kadın & 73 & 4,51 & ,488 & 5,740 & 436 &, $000^{*}$ \\
\hline & Erkek & 365 & 4,08 & ,604 & & & \\
\hline
\end{tabular}

$\left({ }^{*} \mathrm{p}<0.05\right)$

Tablo 5'teki veriler incelendiğinde, cinsiyet değişkenine göre GSA, MYA, MİA alt boyutlarında ve Ölçeğin tamamında istatistiki olarak anlamlı bir farklılık elde edilmiştir. Bu farklılığın kadın katılımcılar lehine olduğu görülmektedir. Katılımcıların lise mezuniyet türlerine göre mesleki yeterlik algıları sonuçları Tablo 6'da verilmiştir.

Tablo 6: Lise Mezuniyet Türü Değişkenine Göre Bă̆ımsız Gruplar t-testi Sonuçları

\begin{tabular}{llllllll}
\hline & & & & \multicolumn{3}{c}{ T testi } \\
\hline Lise Mezuniyet Türü & $\mathbf{n}$ & $\overline{\boldsymbol{x}}$ & ss & t & sd & p \\
\hline \multirow{2}{*}{ GSA } & Genel (Anadolu) & 107 & 4,36 &, 608 &, 282 & 436 &, 778 \\
\cline { 2 - 9 } & Meslek & 331 & 4,34 &, 609 & & & \\
\hline \multirow{2}{*}{ MYA } & Genel (Anadolu) & 107 & 3,88 &, 752 & $-1,726$ & 436 &, 085 \\
\cline { 2 - 9 } & Meslek & 331 & 4,02 &, 722 & & & \\
\hline \multirow{2}{*}{ MİA } & Genel (Anadolu) & 107 & 3,88 &, 934 &,- 036 & 436 &, 971 \\
\cline { 2 - 8 } & Meslek & 331 & 3,89 &, 817 & & & \\
\hline \multirow{2}{*}{ TÜM } & Genel (Anadolu) & 107 & 4,12 &, 615 &,- 631 & 436 &, 528 \\
\cline { 2 - 8 } & Meslek & 331 & 4,16 &, 605 & & & \\
\hline
\end{tabular}

GSA, MYA, MİA ve ölçeğin tümü açısından yapılan t-testi sonuçlarına göre lise mezuniyet türü değişkenine göre istatistiki olarak anlamlı bir fark elde edilememiştir. Öğrenim türlerine göre katılımcıların mesleki yeterlik algılarına yönelik elde edilen sonuçlar Tablo 7'de verilmiştir.

Tablo 7: Öğrenim Türü Değişkenine Göre Bă̆ımsız Gruplar t-testi Sonuçları

\begin{tabular}{lllllll}
\hline & & & & \multicolumn{3}{c}{ T testi } \\
\hline Öğrenim Türü & n & $\bar{x}$ & ss & t & sd & p \\
\hline
\end{tabular}




\begin{tabular}{llllllll}
\hline \multirow{2}{*}{ GSA } & Normal Öğretim & 235 & 4,39 &, 525 & 1,716 & 436 &, 087 \\
\cline { 2 - 8 } & İkinci Öğretim & 203 & 4,29 &, 690 & & & \\
\hline \multirow{2}{*}{ MYA } & Normal Öğretim & 235 & 4,03 &, 644 & 1,339 & 436 &, 181 \\
\cline { 2 - 8 } & İkinci Öğretim & 203 & 3,94 &, 820 & & & \\
\hline \multirow{2}{*}{ MİA } & Normal Öğretim & 235 & 3,88 &, 827 &,- 162 & 436 &, 871 \\
\cline { 2 - 8 } & İkinci Öğretim & 203 & 3,89 &, 870 & & & \\
\hline \multirow{2}{*}{ TÜM } & Normal Öğretim & 235 & 4,19 &, 535 & 1,429 & 436 &, 154 \\
\cline { 2 - 8 } & İkinci Öğretim & 203 & 4,11 &, 680 & & & \\
\hline
\end{tabular}

Tablo 7 incelendiğinde, katılımcıların verdikleri yanıtlara göre GSA, MYA ve MİA alt boyutları ve ölçeğin tamamı için istatistiki olarak anlamlı bir fark tespit edilememiştir. Yaş değişkenine göre katılımcı yanıtlarına yönelik yapılan analiz sonuçları Tablo 8'de verilmiştir.

Tablo 8: Yaş Değişkenine Göre Bă̆ımsız Gruplar t-testi Sonuçları

\begin{tabular}{llllllll}
\hline & & & & \multicolumn{4}{c}{ T testi } \\
\hline Yaş & & $\mathbf{n}$ & $\overline{\boldsymbol{x}}$ & $\mathbf{s s}$ & $\mathbf{t}$ & $\mathbf{s d}$ & $\mathbf{p}$ \\
\hline \multirow{2}{*}{ GSA } & $18-20$ & 280 & 4,35 &, 538 &, 443 & 436 &, 658 \\
\cline { 2 - 8 } & 21 ve üstü & 158 & 4,33 &, 718 & & & \\
\hline \multirow{2}{*}{ MYA } & $18-20$ & 280 & 3,98 &, 688 &,- 514 & 436 &, 607 \\
\cline { 2 - 8 } & 21 ve üstü & 158 & 4,01 &, 805 & & & \\
\hline \multirow{2}{*}{ MİA } & $18-20$ & 280 & 3,82 &, 824 & $-2,060$ & 436 &, $040^{*}$ \\
\cline { 2 - 8 } & 21 ve üstü & 158 & 4,00 &, 875 & & & \\
\hline \multirow{2}{*}{ TÜM } & $18-20$ & 280 & 4,15 &, 556 &,- 249 & 436 &, 804 \\
\cline { 2 - 8 } & 21 ve üstü & 158 & 4,16 &, 691 & & & \\
\hline
\end{tabular}

Tablo 8'e göre katılımcıların MİA alt boyutundaki yanıtlarında istatistiki olarak anlamlı bir fark tespit edilmiştir. Ölçeğin tamamı, GSA ve MİA alt boyutlarında ise anlamlı bir sonuç elde edilememiştir. Katılımcıların bir işyerinde çalışıp çalışmama durumları göz önünde bulundurularak yapılan analiz sonuçları Tablo 9'da verilmiştir.

Tablo 9: Çalışma Durumu Değişkenine Göre Bă̆ımsız Gruplar t-testi Sonuçları

\begin{tabular}{llllllll}
\hline & & & & \multicolumn{5}{c}{ T testi } \\
\hline \multicolumn{2}{c}{ Çalışıyor mu? } & $\mathbf{n}$ & $\overline{\boldsymbol{x}}$ & ss & $\mathbf{t}$ & $\mathbf{s d}$ & $\mathbf{p}$ \\
\hline \multirow{2}{*}{ GSA } & Evet & 187 & 4,30 &, 616 & $-1,288$ & 436 &, 199 \\
\cline { 2 - 9 } & Hayır & 251 & 4,38 &, 602 & & & \\
\hline \multirow{2}{*}{ MYA } & Evet & 187 & 4,00 &, 762 &, 133 & 436 &, 894 \\
\cline { 2 - 9 } & Hayır & 251 & 3,99 &, 710 & & & \\
\hline \multirow{2}{*}{ MİA } & Evet & 187 & 3,88 &, 878 &,- 118 & 436 &, 906 \\
\cline { 2 - 8 } & Hayır & 251 & 3,89 &, 823 & & & \\
\hline \multirow{2}{*}{ TÜM } & Evet & 187 & 4,13 &, 624 &,- 699 & 436 &, 485 \\
\cline { 2 - 8 } & Hayır & 251 & 4,17 &, 595 & & & \\
\hline
\end{tabular}

Tablo 9'a göre, ölçeğin tümünde ve alt boyutlarında çalışma durumu değişkenine göre istatistiki olarak anlamlı bir fark tespit edilememiştir. Katılımcıların öğrenim gördükleri program türlerine göre verdikleri yanıtlara göre elde edilen sonuçlar Tablo 11'de verilmiştir. 
Tablo 41: Program Türü Değişkenine Göre Anova Testi Sonuçları

\begin{tabular}{|c|c|c|c|c|c|c|c|c|c|c|}
\hline & & $\mathbf{N}$ & $\bar{x}$ & $\begin{array}{l}\text { Var. } \\
\text { Kay. }\end{array}$ & $\begin{array}{l}\text { Kar. } \\
\text { Top. }\end{array}$ & sd & $\begin{array}{l}\text { Kar. } \\
\text { Ort. }\end{array}$ & $\mathbf{F}$ & $\mathbf{p}$ & Fark \\
\hline \multirow{5}{*}{ GSA } & Elektrik & 71 & 4,56 & G. aras1 & 5,097 & 3 & 1,699 & 4,700 & ,003 & $1-2,1-3$ \\
\hline & Elektronik & 117 & 4,32 & G. içi & 156,876 & 434 & ,361 & & & \\
\hline & Kontrol ve Otomasyon & 162 & 4,24 & Toplam & 161,974 & 437 & & & & \\
\hline & Radyo ve Televizyon & 88 & 4,38 & & & & & & & \\
\hline & Toplam & 438 & 4,34 & & & & & & & \\
\hline \multirow{5}{*}{ MYA } & Elektrik & 71 & 4,09 & G. aras1 & 5,837 & 3 & 1,946 & 3,699 & ,012 & $3-4$ \\
\hline & Elektronik & 117 & 4,06 & G. içi & 228,265 & 434 &, 526 & & & \\
\hline & Kontrol ve Otomasyon & 162 & 3,84 & Toplam & 234,102 & 437 & & & & \\
\hline & Radyo ve Televizyon & 88 & 4,09 & & & & & & & \\
\hline & Toplam & 438 & 3,99 & & & & & & & \\
\hline \multirow{5}{*}{ MİA } & Elektrik & 71 & 4,10 & G. aras1 & 4,312 & 3 & 1,437 & 2,021 & 110 & \\
\hline & Elektronik & 117 & 3,87 & G. içi & 308,720 & 434 &, 711 & & & \\
\hline & Kontrol ve Otomasyon & 162 & 3,80 & Toplam & 313,032 & 437 & & & & \\
\hline & Radyo ve Televizyon & 88 & 3,88 & & & & & & & \\
\hline & Toplam & 438 & 3,88 & & & & & & & \\
\hline \multirow{5}{*}{ TÜM } & Elektrik & 71 & 4,32 & G. aras1 & 4,380 & 3 & 1,460 & 4,035 & ,008 & $1-3$ \\
\hline & Elektronik & 117 & 4,17 & G. içi & 157,036 & 434 &, 362 & & & \\
\hline & Kontrol ve Otomasyon & 162 & 4,04 & Toplam & 161,417 & 437 & & & & \\
\hline & Radyo ve Televizyon & 88 & 4,21 & & & & & & & \\
\hline & Toplam & 438 & 4,15 & & & & & & & \\
\hline
\end{tabular}

Yapılan analizler sonucunda, ölçeğin $\operatorname{GSA}\left(\mathrm{F}_{(3-434)}=4,700 ; \mathrm{p}<.05\right)$ ve MYA $\left(\mathrm{F}_{(3-434)}=3,699\right.$;

$\mathrm{p}<.05)$ boyutlarında ve Ölçeğin tamamında $\left(\mathrm{F}_{(3-434)}=4,035 ; \mathrm{p}<.05\right)$ anlamlı farklılı̆̆a rastlanmıştır.

Farklılığın hangi gruplar arasında olduğunu belirlemek amacıyla yapılan Scheffe analizine göre; GSA boyutunda Elektrik ve Elektronik ile Elektrik ve Kontrol ve Otomasyon Teknolojisi programları arasında Elektrik programı lehine anlamlı farklılık tespit edilmiştir. MYA boyutunda Kontrol ve Otomasyon ile Radyo ve Televizyon programları arasında Radyo ve Televizyon programı lehine anlamlı farklılık tespit edilmiştir. Ölçeğin tamamı için ise Elektrik ve Kontrol ve Otomasyon Teknolojisi programları arasında Elektrik programı lehine anlamlı farklılık tespit edilmiştir.

\section{Sonuç Tartışma ve Öneriler}

Üniversite öğrencilerinin öğrenim gördükleri mesleki programa yönelik yeterlik algılarını belirlemek amacıyla Mesleki Yeterlilik Algısı ölçeği geliştirilmiştir. Ölçeğin geliştirme aşamalarıdaki açımlayıcı ve doğrulayıcı faktör analizi sonuçlarına göre, ölçeğin geçerli ve güvenilir olduğu sonucuna ulaşılmıştır. Bu bakımdan üniversite öğrencilerinin Mesleki Yeterlik Algılarını ölçmeye yönelik çalışmalarda kullanılmasının uygun olduğu söylenebilir. 
Mesleki Yeterlilik Algısı ölçeğinin uygulanması sonucunda cinsiyet değişkenine göre ölçeğin tamamı ve alt boyutlarında kadın katılımcılar lehine anlamlı bir farklılık tespit edilmiştir. Elde edilen bu sonuca benzer şekilde Ng, Lam ve Feldman (2016) çalışmalarında mesleki açıdan kadın ve erkekler arasında, kadınlar lehine zayıf bir oranda bir farklılık belirlemiştir. Bu sonuç doğrultusunda kadınların mesleki yeterlik algılarının erkeklere göre daha fazla olduğu ifade edilebilir. Aynı zamanda Roth, Purvis ve Bobko (2012) çalışmalarında, iş performansına göre cinsiyet farklılıklarının oldukça düşük düzeyde olduğu sonucuna ulaşmıştır.

Yaş değişkenine göre Mesleki İlgi Algısı boyutunda 21 yaş ve üstü katılımcıların mesleki ilgilerinin daha yüksek olduğu belirlenmiştir. Bu sonuca etki eden faktör olarak, bu katılımcıların yakın bir zamanda mezun olacakları için çalışma hayatına daha yakın olmaları ifade edilebilir. Aynı zamanda, bu katılımcıların mesleki programdaki deneyimleri de mesleki yeterlik algılarına olumlu şekilde etki etmiştir denilebilir. Bireylerin, zamanla daha fazla deneyim kazanmaları mesleklerine yönelik olumlu algılarını artmaktadır (Colarelli ve Bishop, 1990; Lee, Carswell ve Allen, 2000). Bu durum da, mesleki yeterlik algısının mesleki programdaki deneyimin etkisiyle zamanla arttığı şeklinde ifade edilebilir. Çünkü bireylerin mezuniyet sonrası istihdam edilmelerindeki en önemli etken mesleki yeterliklerinin beklenen düzeyde olmasıdır. Bu beklentiyi karşılayacak şekilde bireylerde mesleki yeterlik algısının oluşması, mesleki programdaki deneyimleri sonrasında artacaktır. Son olarak yaş ve örgütsel bağlılık arasındaki olumlu lişki (Ng ve Feldman, 2010) de bireylerin mesleki yeterlik algılarının olumlu şekilde etkilenmesinde önemli bir etken olarak görülebilir.

Katılımcıların öğrenim gördükleri program türüne göre yapılan analizlerde, ölçeğin tümünde Elektrik ile Kontrol ve Otomasyon Teknolojisi programları arasında Elektrik programı lehine anlamlı farklılık tespit edilmiştir. Görev Sorumluluğu Algısı boyutunda Elektrik ve Elektronik ile Elektrik ve Kontrol ve Otomasyon Teknolojisi programları arasında Elektrik programı lehine anlamlı farklılık tespit edilmiştir. Mesleki Yeterlik Algısı boyutunda ise Kontrol ve Otomasyon ile Radyo ve Televizyon programları arasında Radyo ve Televizyon programı lehine anlamlı farklılık tespit edilmiştir.

Katılımcıların mezun oldukları lise türü veya programlardaki öğrenim türüne göre yapılan analizlerde istatistiki olarak anlamlı bir farklılık tespit edilememiştir. Okul başarısı ve mesleki ilgi 
öğrencilerin meslek seçimlerini etkilemektedir. Özellikle bireylerin mesleki ilgi düzeyleri, mesleki seçimlerini en güçlü şekilde etkileyen değişken olarak belirlenmiştir (Volodinave Nagy, 2016). Çalışmadan elde edilen bu sonuca göre, öğrencilerin üniversite tercihlerinde mesleki ilgilerini göz önünde bulundurarak mesleki program tercihinde bulundukları belirtilebilir. Aynı zamanda, mesleki program tercihinde lise mezuniyet başarısının da etkili belirlenmiştir (Nagy, Trautwein ve Maaz, 2012). İlgili mesleki programa yerleşen öğrencilerin sınav başarı puanlarının birbirine yakın olduğu düşünüldüğünde, mesleki yeterlik ve ilgi boyutlarının benzer düzeyde olması sonucu çalışmannın beklenen sonuçları arasında ifade edilebilir.

Ayrıca katılımcıların hali hazırda çalışma durumları ile mesleki yeterlik algıları incelendiğinde de istatistiki olarak anlamlı bir farklılık tespit edilememiştir. Bu değişkenler dikkate alındığında öğrenim gördükleri mesleki programı tercih etmeden önce mesleki yeterlilik ve ilgilerinin yeterli olduğu ifade edilebilir. Diğer bir ifade ile çalışanların eşit derecede motive ve üretken olmasının (Roth, Purvis ve Bobko, 2012) etkili olduğu belirtilebilir. Alan yazında program tercih nedenleri arasında seçtikleri alana duydukları ilgi, mezuniyet sonrası iş bulma imkanı, cinsiyet, yaş ve mezun olduğu lise türü faktörlerin etkili olduğu yer almıştır (Dinç, 2008; KorkutOwen, Kepir, Özdemir, Ulaş ve Yılmaz, 2012; Kuijpers ve Meijers 2012; Pappas ve Kounenou, 2011). Bu etkenler ve katılımcıların çalışma durumları dikkate alındığında, mesleki programda öğrenim gören öğrencilerin aynı zamanda bir firmada çalışmalarının mesleki yeterlik algılarına etkisi olmadığı ifade edilebilir.

Mesleki eğitim sonucunda ortaya çıkan mesleki yeterlikler, aynı zamanda mesleki programların en temel amacıdır. Çünkü MYO'ların amaçlarından birisi de mesleki eğitimin niteliğini ve yeterliliğini yükseltmektir (İçli, 2007). Çalışma sonucunda öğrencilerin beklenen düzeyde mesleki yeterliklere sahip olması mesleki programlarının görevini yerine getirdiğinin en açık kanıtıdır. Özellikle öğrencilerin mesleki yeterlik algılarındaki yeterlik boyutu ön plana çımaktadır. Çünkü yeterlilik kavramı, mesleki değerlendirmenin hedef yapısı olarak bilgi kavramından daha değerlidir (Deutscher ve Winther, 2018). Diğer bir ifade ile, yeterlik kavramı bilginin uygulamadaki hali şeklinde ifade edilebilir. Sektördeki firmalar personel istihdamında bazı yeterliklerin kazanılmış olmasını göz önünde bulundurmaktadır. Bunlar arasında potansiyel personellerin mesleki açıdan teknik beceri ve tecrübeye sahip olması yer almaktadır (Kayır ve diğ., 2006). Mesleki programlardaki öğrenciler dört dönem boyunca edindikleri deneyim ile birlikte 
aldıkları akademik başarı sonucu mezun olmaktadırlar. Mezuniyet sonrası sektördeki firmalar tarafından istihdam edilecekleri alanlardaki mesleki yeterliklere sahip olmaları beklenmektedir. Fakat mezunların beklenen düzeyde yeterliklere sahip olmadıkları ifade edilmektedir (Vurgun, 2008). Bu nedenle potansiyel personellerin ek sertifikalar almaları talep edilebilmektedir (GülKoçak, 2006). Bu sayede ihtiyaç duyulan alanlardaki mesleki yeterlikleri beklenen düzeylere çıkarılabilir. Bu tür durumlar da hem mezunlar hem de firmalar için zaman ve finansal kayıplara neden olmaktadır. Öğrencilerin mesleki yeterlik algılarını ölçebilecek araçların geliştirilmesi ile, firmaların yeterlilik algısı yüksek bireylere ulaşmaları ve bunları istihdam etmeleri sağlanabilir. Çalışma kapsamında geliştirilen Mesleki Yeterlik Algısı Ölçeği ile bu ihtiyaç giderilebilir. Ayrıca katılımcıların mesleki yeterlik algılarının yüksek düzeyde olması, firmaların beklentilerinin karşılanabildiği şeklinde ifade edebilir. Öğrencilerin mesleki yeterlik algılarını ölçebilecek bu tür ölçme araçlarının geliştirilmesi ile öğrencilerin algıları belirlenebilir. Bu sayede mesleki eğitim boyutundaki öğrencilerin işyeri ortamlarına uyumlarına yardımcı olunabilir (Panadero, Garcia ve Fraile, 2018). Diğer bir ifadeyle, öğrencilerin öz-değerlendirme yapmalarına imkan tanıyan araçlar ile, istihdam edilmelerine de kolaylık sağlanabilir. Öğrencilerin öz-değerlendirme yapabilmesi için, öğretim elemanlarının yardımcı olmaları gerekir (Panadero, Garcia ve Fraile, 2018). Bu sayede öğrencilerin daha doğru değerlendirmeler yapmaları sağlanabilir.

Sektördeki firmalar mesleki yeterlik algısı yüksek potansiyel personelleri belirlemek amacıyla bu ölçeği uygulayabilir. Bu sayede yukarıda belirtildiği üzere zaman ve maddi kayıpların önüne geçilebilir. Mesleki yeterlik algısı ölçeği öğrencilerin öğrenimleri süresince uygulanabilir. $\mathrm{Bu}$ sayede, hem öğretim elemanlarının hem de öğrencilerin mesleki yeterlik algı düzeylerine erişimi sağlanabilir. Çalışmada meslek yüksekokulu üzerinden elde edilen veriler analiz edilmiştir. Farklı birimlerde öğrenim görmekte olan öğrenciler ile çalışmalar yapılabilir. Son olarak, öğrenimleri süresince bir firmada çalışan öğrenciler için, öğrenim gördükleri mesleki programla ilişkili bir firmada çalışma durumları göz önünde bulundurularak mesleki yeterlik algı düzeylerini ölçebilecek çalışmalar yürütülebilir.

Etik Kurul İzin Bilgisi: Bu araştırma, İstanbul Üniversitesi-Cerrahpaşa Sosyal ve Beşeri Bilimler Araştırmaları Etik Kurulu'nun 07/04/2020 tarihli 74555795-050.01.04 sayılı kararı ile alınan izinle yürütülmüş̧ı̈r. 


\section{Kaynakça}

Bandura, A. (1977). Self-efficacy: toward a unifying theory of behavioral change. Psychological review, 84(2), 191-215.

Barrick, R. K. (2019). Competence and Excellence in Vocational Education and Training. In Handbook of Vocational Education and Training: Developments in the Changing World of Work, 1-12.

Baumgartner, H., \& Homburg, C. (1996). Applications of structural equation modeling in marketing and consumer research: A review. International Journal of Research in Marketing, 13(2), 139-161.

Brockmann, M., Clarke, L., Méhaut, P., Winch, C. (2008). Competence-based vocational education and training (VET): The cases of England and France in a European perspective. Vocational and Learning, 1, 227-244.

Büyüköztürk, Ş., Çakmak, E.K., Akgün, Ö.E., Karadeniz, Ş. ve Demirel, F. (2008). Bilimsel Araştırma Yöntemleri. Ankara: Pegem.

Colarelli, S. M., \& Bishop, R. C. (1990). Career commitment: Functions, correlates, and management. Group \& Organization Studies, 15(2), 158-176.

Comrey, A. L. (1988). Factor-analytic methods of scale development in personality and clinical psychology. Journal of consulting and clinical psychology, 56(5), 754.

Çokluk, Ö., Şekercioğlu, G. ve Büyüköztürk, Ş. (2012). Sosyal bilimler için çok değiş̧kenli istatistik: SPSS ve Lisrel Uygulamaları. Pegem Akademi Yayınc1lık, Ankara.

Deutscher, V., Winther, E. (2018). Instructional sensitivity in vocational education. Learning and Instruction 53, 21-33.

Dinç, E. (2008). Meslek seçiminde etkili faktörlerin incelenmesi: Meslek yüksekokulu-muhasebe programı öğrencileri üzerine bir araştırma. Kocaeli Üniversitesi Sosyal Bilimler Enstitüsü Dergisi, 2(16), 90-106.

Eilström, P. E., \& Kock, H. (2008). Competence development in the workplace: concepts, strategies and effects. Asia pacific education review, 9(1), 5-20.

Field, A. (2005). Discovering Statistics Using SPSS. London: Sage. 
Gül-Koçak, H. (2006). Bilgisayar teknolojisi ve programlama eğitim programının sorunları. Yüksek lisans tezi. Çukurova Üniversitesi, Sosyal Bilimler Enstitüsü, Eğitim Bilimleri Anabilim Dal1.

Harper, N. W., Daane, C. J. (1998). Causes and reductions of math anxiety in preserviceelementary teachers. Action in Teacher Education, 19, 29-38.

İçli, G.E., (2007). İşletmelerin Meslek Yüksekokulu mezunları ile ilgili görüşleri ve beklentileri (Lüleburgaz ilçe sınırlarında faaliyet gösteren işletmeler üzerine bir araştırma), Ege Üniversitesi IV. Ulusal Meslek Yüksekokulu Sempozyumu. İzmir.

Karasar, N. (2009). Bilimsel Araştırma Yöntemi. Ankara: Nobel.

Kalaycı, Ş. (2009). SPSS Uygulamalı Çok Değişkenli İstatistik Teknikleri. Asil Yayın, 4. Bask1.

Kayır, Ö, Karaca, Ş., Şenyüz, Y., Söğütlü, C., Yayman, H., Kılıç, H. (2006). İstanbul Ticaret Odası: İ̧̧ dünyasının mesleki eğitime bakışı. Mega Ajans Matbaacılık, İstanbul.

Klotz, V. K., Billett, S., \& Winther, E. (2014). Promoting workforce excellence: formation and relevance of vocational identity for vocational educational training. Empirical research in vocational education and training, 6(6), 1-20.

Korkut-Owen, F., Kepir, D. D., Özdemir, S., Ulaş, Ö., \& Yılmaz, O. (2012). Üniversite öğrencilerinin bölüm seçme nedenleri. Mersin Üniversitesi Eğitim Fakültesi Dergisi, 8(3), $135-151$

Kuijpers, M., Meijers, F. (2012). Learning for now or later? Career competencies among students in higher vocational education in the Netherlands. Studies in Higher Education, 37(4), 449467.

Lee, K., Carswell, J. J., \& Allen, N. J. (2000). A meta-analytic review of occupational commitment: relations with person-and work-related variables. Journal of applied psychology, 85(5), 799.

Leney T. (2002). Achieving the Lisbon goal: The contribution of VET. $<$ http://ec.europa.eu/education/policies/2010/studies/maastricht_en.pdf $>$ Erişim: Eylül 2016.

Lindberg, O., Rantatalo, O. (2015). Competence in professional practice: A practice theory analysis of police and doctors. Human relations, 68(4) 561-582.

Mulder M, Winterton J (2017) Introduction. In Competence-based vocational and professional education. Bridging the worlds of work and education. 
Mulder, M., Weigel, T., \& Collins, K. (2006). The concept of competence in the development of vocational education and training in selected EU member states: A critical analysis. Journal of Vocational Education and Training, 59(1), 65-85.

Nagy, G., Trautwein, U., \& Maaz, K. (2012). Fähigkeits-und interessenprofile am ende der sekundarstufe 1: Struktur, spezifikation und der zusammenhang mit gymnasialzweigwahlen. Zeitschrift für Pädagogische Psychologie.

Ng, T. W., \& Feldman, D. C. (2010). The relationships of age with job attitudes: A meta-analysis. Personnel Psychology, 63(3), 677-718.

Ng, T. W., Lam, S. S., \& Feldman, D. C. (2016). Organizational citizenship behavior and counterproductive work behavior: Do males and females differ?. Journal of Vocational Behavior, 93, 11-32.

Nokelainen, P., Pylväs, L., \& Rintala, H. (2018). Skills competitions for promoting vocational excellence. In Handbook of Vocational Education and Training: Developments in the Changing World of Work, 1-13.

Özdaşlı, K. (2008). Bireysel kariyer planlamada etkili olan faktörler ve üniversitelerin etkisi üzerine bir araştırma, Süleyman Demirel Üniversitesi Sosyal Bilimler Enstitüsü, Yayınlanmamış Yüksek Lisans Tezi.

Panadero, E., Garcia, D., \& Fraile, J. (2018). Self-assessment for learning in vocational education and training. In Handbook of Vocational Education and Training: Developments in the Changing World of Work, 1-12.

Pappas, T. S., ve Kounenou, K. (2011). Career decision making of Greek post secondary vocational students: the impact of parents and career decision making selfefficacy. Procedia - Social and Behavioral Sciences, 15, 3410-3414.

Pylväs L, Nokelainen P. (2018). Global competence: towards intercultural understanding. In: Handbook of vocational education and training: developments in the changing world of work.

Roth, P. L., Purvis, K. L., \& Bobko, P. (2012). A meta-analysis of gender group differences for measures of job performance in field studies. Journal of Management, 38(2), 719-739.

Schermelleh-Engel, K., \& Moosbrugger, H. (2003). Evaluating the fit of structural equation models: Tests of significance and descriptive goodness-of-fit measures. Methods of Psychological Research Online, 8(2), 23-74. 
Schreiber, J. B., Nora, A., Stage, F. K., Barlow, E. A., \& King, J. (2006). Reporting structural equation modeling and confirmatory factor analysis results: A review. The Journal of educational research, 99(6), 323-338.

Sezgin, İ. (2000). Mesleki ve teknik eğitimde program geliştirme. 4. bs. Ankara: Nobel Yayınları.

Turan, S. (2002). Teknolojinin okul yönetiminde etkin kullanımında eğitim yöneticisinin rolü. Kuram Ve Uygulamada Ĕ̆itim Yönetimi, 30, 271-88.

Tūtlys V, Aarna O. (2017). Competence-based approach in the education reforms of Lithuania and Estonia. In: Competence-based vocational and professional education. Bridging the worlds of work and education, 381-406.

Tyson R (2018). Educating for vocational excellence. In Handbook of vocational education and training: developments in the changing world of work, 1-16.

Volodina, A., \& Nagy, G. (2016). Vocational choices in adolescence: The role of gender, school achievement, self-concepts, and vocational interests. Journal of Vocational Behavior, 95, $58-73$.

Vurgun, L. (2008). Bilgi toplumu açısından Türkiye'deki meslek yüksekokullarının örgütlenme problemleri ve çözüm önerileri. Doktora tezi. Kocaeli Üniversitesi, Sosyal Bilimler Enstitüsü, İşletme Anabilim Dalı, Yönetim ve Organizasyon Programı. 